\title{
Factors Affecting Work Performance among Nurses in Delivering Health Service for the National Health Insurance Patients at Dr. Moewardi Hospital, Surakarta
}

\author{
Nureesa Doloh'), Didik Tamtomo'), Endang Sutisna Sulaeman²) \\ ${ }^{1)}$ Masters Program in Public Health, Universitas Sebelas Maret \\ 2)Faculty of Medicine, Universitas Sebelas Maret
}

\begin{abstract}
Background: The performances of the doctors and the nurses are especially important in accomplishing health care in a continuous and effective way. It is important to examine all organizational, individual, social factors that especially affect the performances of the doctors and nurses holistically. The purpose of this study was to assess factors affecting work performance among nurses in delivering health service for the national health insurance patientsat Dr. Moewardi Hospital, Surakarta.

Subjects and Method: A cross-sectional study was carried out in Dr. Moewardi Hospital, Surakarta, Central Java. A sample of 150 nurseswho provided health services to the National Health Insurance patientswas selectedfor this study by proportional random sampling. The dependent variable was work performance. The independent variables were work satisfaction, work motivation, and supervision. The data were collected by questionnaire and analyzed by path analysis run on Stata 13.
\end{abstract}

Results: Work performance was affected by work satisfaction $(b=0.88 ; 95 \% \mathrm{CI}=0.05$ to 1.71 ; $\mathrm{p}=0.037$ ), work motivation $(\mathrm{b}=0.81 ; 95 \% \mathrm{CI}=-0.06$ to $1.68 ; \mathrm{p}=0.070)$, and supervision $(\mathrm{b}=0.97$; $95 \% \mathrm{CI}=0.18$ to $1.76 ; \mathrm{p}=0.016)$. Work performance was also indirectly affected by motivation.

Conclusion:Work performance is affected by work satisfaction, work motivation, and supervision. Work performance is also indirectly affected by motivation.

Keywords: work performance, motivation, supervision, satisfaction, nurses

\section{Correspondence:}

Nureesa Doloh. Masters Program in Public Health, Universitas Sebelas Maret, Jl. Ir. Sutami No. 36 A, Surakarta 57126, Central Java.Email: nursenuris2015@gmail.com.Mobile:+62895414785888.

\section{BACKGROUND}

Health services, especially from the public sector, still have many obstacles and barriers, especially in terms of quality of service (Mote, 2008). The World Bank report from 157 countries shows that Indonesia is at the $135^{\text {th }}$ place in the quality of public services. A service is considered satisfactory if it meets the needs and expectations of the community. If people feel dissatisfied with the service provided, it indicates that public service in a country is in an ineffective and inefficient state (Endang, 2008).
A nurse is one of the health personnel team that helps determine the quality of service in the hospital. Quality of service in the hospital in terms of nursing includes aspects of the number and ability of professionals, work motivation, funds, facilities and supporting equipment, hospital management that needs to be refined and adapted to the development of science and technology. Nursing services are forms of professional service and an integral part of the overall healthcare effort.

Nursing service is the main service that must be done to achieve the healing of hospitalized patients. In supporting the 
healing of hospitalized patients, the role of nurses is crucial in providing health care in the form of nursing care, providing education to patients about things that support health and accelerate the healing of disease (Nurachmah, 2011).

The performance of health services is a quality of service measured based on the results of self-assessment (patient rights fulfillment and staffing needs) and review of patient records. Self assessment is an activity to see the condition of existing health services in terms of fulfilling the rights of patients and health care staff. Review patient records aim to determine that key information is accurately and accurately recorded on the patient's health record and the patient obtains services in accordance with the standards. Patient flow analysis is a method to take into account the amount of time patients spent in getting services. Review of patient records and patient flow analysis when receiving health care consist of waiting time and service time (Wibowo, 2009).

Quality services are patient-oriented services, affordable and readily available. Based on that, the purpose of this study is to analyze the determinants that affect the performance of nurses in serving patients BPJS in Dr. Moewardihospital, Surakarta.

\section{SUBJECTS AND METHOD}

\section{Study Design}

This was an analytic observational study with a cross sectional design. The study was conducted at Dr. Moewardi hospital, Surakarta, Central Java.

\section{Population and Sample}

Target population in this study was nurse or executive staff who served in the wards of class I, II and III, Dr. Moewardi hospital, Surakarta, Central Java. A sample of 150 nurses was selected by proportional random sampling.

\section{Study Variables}

The dependent variable is the performance of the nurse. The independent Variables include job satisfaction, work motivation and supervision.

\section{Operational Definition of Variables} Job satisfaction was defined as nurse behavior to work, work situation, and nurse cooperation with their leader. The data were collected by questionnaire. The measurement scale was continuous, but for the purpose of data analysis, it was transformed into dichotomous, coded o for low and 1 for high satisfaction.

The motivation of work was defined as an impulse within a nurse as a result of the inward and outer influences, and then the impulse leads to, directs, and organizes the behavior to do the work. The data were collected by questionnaire. The measurement scale was continuous, but for the purpose of data analysis, it was transformed into dichotomous, coded o for weak and 1 for strong.

Supervision was defined as an activity planned by a leader through guidance, direction, observation, motivation and evaluation of the staff in carrying out activities or daily tasks. The data were collected by questionnaire. The measurement scale was continuous, but for the purpose of data analysis, it was transformed into dichotomous, coded o for poor and 1 for good.

Nurse performance was defined as the work of nurses in carrying out their work is implementing the nursing process (from assessment to evaluation). The data were collected by questionnaire. The measurement scale was continuous, but for the purpose of data analysis, it was transformed into dichotomous, coded o for poor and 1 for good. 
Journal of Health Policy and Management (2018), 3(1): 20-25

https://doi.org/10.26911/thejhpm.2018.03.01.03

\section{Data Analysis}

The data were analyzed by path analysis run on Stata 13.

\section{Research Ethics}

The research ethics include informed consent, anonymity, confidentiality and ethical clearance. The ethical clearance in this study was obtained from Dr. Moewardi hospital, Surakarta, Central Java, and declared as worthy of ethics based on the decision letter number: 455 / IV / HREC / 2018.

\section{RESULTS}

\section{Univariate Analysis}

Table 1 shows that subjects with low job satisfaction consisted of 51 people (34.0\%), and those with high job satisfaction were 99 people (66.0\%). Low-motivated nurses were 49 people $(32.7 \%)$, and those with high work motivation were 101 (67.3\%). Nurses who received less supervision were 62 people (41.3\%), and who get good supervision were 88 people (58.7\%). Nurses who have less performance were 57

people (38.0\%), and those who have good performances were 93 people (62.0\%).

Table 1. Univariate analysis of variables

\begin{tabular}{lcc}
\hline \multicolumn{1}{c}{ Variables } & n & (\%) \\
\hline Satisfaction & & \\
Low & 51 & 34.0 \\
High & 99 & 66.0 \\
Motivation & & \\
Low & 49 & 32.7 \\
High & 101 & 67.3 \\
Supervision & & \\
Fair & 62 & 41.3 \\
Good & 88 & 58.7 \\
Importance & & \\
Less & 57 & 38.0 \\
Good & 93 & 62.0 \\
\hline
\end{tabular}

\section{Bivariate Analysis}

The bivariate analysis was used to see the relationship of independent variables (job satisfaction, work motivation and supervision) and the dependent variable of the dependent variable (nurse performance). The result of bivariate analysis can be seen in table 2.

Table 2. Bivariate analysis influence independent variables with nurse performance

\begin{tabular}{|c|c|c|c|c|c|c|c|c|c|}
\hline \multirow[t]{2}{*}{ Variables } & \multicolumn{2}{|c|}{$\begin{array}{c}\text { Poor } \\
\text { Performance }\end{array}$} & \multicolumn{2}{|c|}{$\begin{array}{c}\text { Good } \\
\text { Performance }\end{array}$} & \multicolumn{2}{|c|}{ Total } & \multirow[t]{2}{*}{ OR } & \multirow{2}{*}{$\begin{array}{c}\mathbf{9 5 \%} \\
\mathbf{C I}\end{array}$} & \multirow[t]{2}{*}{$\mathbf{p}$} \\
\hline & $\mathrm{n}=57$ & $\%$ & $\mathbf{n}=93$ & $\%$ & $n=150$ & $\%$ & & & \\
\hline \multicolumn{10}{|l|}{ Satisfaction } \\
\hline Low & 31 & 60.8 & 20 & 39.2 & 51 & 100 & \multirow[t]{2}{*}{2.41} & 1.05 to & \multirow[t]{2}{*}{$<0.001$} \\
\hline High & 26 & 26.3 & 73 & 73.7 & 99 & 100 & & $5 \cdot 53$ & \\
\hline \multicolumn{10}{|l|}{ Motivation } \\
\hline High & $\begin{array}{l}31 \\
26\end{array}$ & 63.3 & 18 & 36.7 & 49 & 100 & \multirow{2}{*}{2.25} & 0.94 to & \multirow{2}{*}{0.007} \\
\hline \multicolumn{8}{|l|}{ Supervision } & & \\
\hline Less & 36 & 58.1 & 26 & 41.9 & 62 & 100 & \multirow[t]{2}{*}{2.65} & 1.20 to & \multirow[t]{2}{*}{$<0.001$} \\
\hline Good & 21 & 23.9 & 67 & 76.1 & 88 & 100 & & 5.83 & \\
\hline
\end{tabular}

\section{The results of path anaysis}

Table 3 showed that there was a significant relationship between work satisfaction, work motivation, and supervision on the performance of nurse.

Nurse performance was affected by nurse satisfaction $(b=0.88 ; 95 \% \mathrm{CI}=0.05$ to $1.71 ; \mathrm{p}=0.037)$, work motivation $(\mathrm{b}=$ $0.81 ; 95 \% \mathrm{CI}=-0.06$ to $1.68 ; \mathrm{p}=0.070$ ), and supervision $(b=0.97 ; 95 \% C I=0.18$ to 1.76 ; $\mathrm{p}=$ 0.016). Work satisfaction was affected by strong motivation $(b=2.25 ; 95 \% \mathrm{CI}=$ 1.46 to 3.03 ; $\mathrm{p}<0.001$ ). 


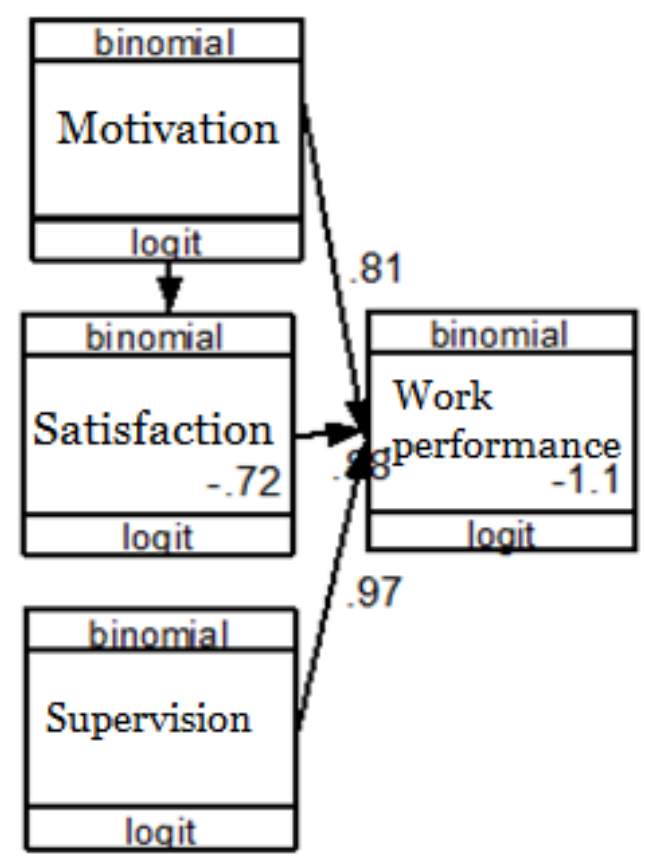

Figure 1. Path analysis model

Table 3. The result of path analysis

\begin{tabular}{|c|c|c|c|c|c|c|}
\hline \multirow[b]{2}{*}{ Dependent Variable } & & \multirow[b]{2}{*}{$\begin{array}{c}\text { Independent } \\
\text { variable }\end{array}$} & \multirow[b]{2}{*}{ b } & \multicolumn{2}{|c|}{$95 \% \mathrm{CI}$} & \multirow[b]{2}{*}{$\mathbf{p}$} \\
\hline & & & & $\begin{array}{l}\text { Lower } \\
\text { Limit }\end{array}$ & $\begin{array}{l}\text { Upper } \\
\text { Limit }\end{array}$ & \\
\hline Direct Effect & & & & & & \\
\hline Nurse performance & $\leftarrow$ & Work Satisfaction & 0.88 & 0.05 & 1.71 & 0.037 \\
\hline Nurse performance & $\leftarrow$ & Work Motivation & 0.81 & -0.06 & 1.68 & 0.070 \\
\hline Nurse performance & $\leftarrow$ & Supervision & 0.97 & 0.18 & 1.76 & 0.016 \\
\hline $\begin{array}{l}\text { Indirect Effect } \\
\text { Satisfaction } \\
\text { N observation= }=150 \\
\text { Log likelihood }=-162.54\end{array}$ & $\leftarrow$ & Motivation & 2.25 & 1.46 & 3.03 & $<0.001$ \\
\hline
\end{tabular}

\section{DISCUSSIONS}

\section{The relationship between work satisfaction and nurse perform- ance}

The result of analysis showed that work satisfaction affected nurse performance. Nurse who had high work satisfaction were o.88 times more likely to had good performance.

The result of this study is consistent with a study by Aron (2015), which stated that there was a positive relationship between nurse work satisfaction and the quality of health services by nurse.
Work satisfaction related to attitudes of employees to the work itself, work situation, cooperation between the leadership, and other employees. According to Blum, work satisfaction wasa general attitude from the result of some special attitudes toward work factors, adjustments, and individual social relationships outside of work (Suyanto, 2008). Service to the customers caused or affected patient satisfaction. The nurse's customer service was a service provided by an employee and other parts of the organization, just like a businessman with his suppliers. 
Journal of Health Policy and Management (2018), 3(1): 20-25

https://doi.org/10.26911/thejhpm.2018.03.01.03

\section{The relationship between work motivation and the performance of nurses}

The result of analysis showed that there was an effect of work motivation on the performance of nurse. Nurse with strong motivation were 0.81 times more likely to had good performance compared to nurse with low work motivation.

The result of this study was in line with a study by Katrina et al. (2014), which evaluated the factors related to the performance of the nurses in registering or recording the patients. The results showed that the factors that affected the performance of nurses were motivation factors.

Motivation was a concept in using the power that work toward or in the individual to begin and explain a behavior. The main significance of motivation was the encouragement that moved a person to perform an activity. Motivation was a process of willingness to do high-level business to achieve organizational goals conditioned by the ability of the business to satisfy the needs of some individuals. The process of motivation was directed toward achieving goals, therefore, motivating people was a management process to influence employees behavior based on the knowledge about what made the person move(Suarly and Bachtiar, 2009).

\section{The relationship between super- vision and the performance of nurses}

The result of analysis showed that there was an effect of supervision on the nurse performance. Nurses who got good supervision were 0.97 times more likely to have good performance compared to nurse with lack of supervision.

The result of this study was in line with a study by Amsrud et al. (2015), which analyzed the effect of clinical supervision factors on the performance of nursing students in conducting clinical practice. The results showed that supervision significantly related to the personal ability of nursing practice students.

Supervision activities were planned activities by a manager through the activeties of guidance, direction, observation, motivation, and evaluation of his/her staff in doing activities or daily tasks of holistic nursing in the context of professional nursing. In practice, supervision was not only whether all nursing staff perform their duties as well as possible which in accordance with the instructions or conditions outlined, but also to improve ongoing nursing process (Mangkunegara, 2013). So, in the supervision activities, everyone involved was not as a passive executive, but together as partners who have ideas, opinions, and experiences that need to be heard, appreciated, and participated in the improvement of the activities process including the nursing process. Therefore, supervision was a dynamic activity that could increase motivation and satisfaction among the people who were involved including leaders, members, or clients and their families.

\section{The relationship between work motivation and work satisfaction}

The result of analysis showed that there was an effect of work motivation on work satisfaction. Nurse with strong motivation were 2.25 times more likely to get higher work satisfaction compared to nurse with weak motivation.

The result of this study was in line with a study by Aly and Shanaway (2016), which analyzed the effect of nurses satisfaction on work assessment and nurses motivation and its impact on their performance. The result of this study concluded that nurse satisfaction toward job assessment has direct effect on nurses' work motivation. The nurses satisfaction on work 
assessment was directly and indirectly affected the performance of the nurses.

Motivation was a concept in using the power that work toward or in the individual to begin and explain a behavior. The main significance of motivation was the encouragement that moved a person to perform an activity (Robbins, 2007).

Motivation was an encouragement that came from within an employee due to the influence that came from inside and outside, then the encouragement generated, directed, and organized the behavior to do a job.

\section{REFERENCES}

Aly N, Shanaway S (2016). The Influence of Performance Appraisal Satisfaction on Nurse's Motivation and Their Work Outcomes in Critical Care and Toxicology Units. European Scientific Journal, 12(20).

Amsrud KE, Lyberg A, Severinsson E (2015). The influence of clinical supervision and its potential for enhancing patient safety - Undergraduate nursing students' views, Journal of Nursing Education and Practice, 5(6). doi: 10.5430/jnep.v5n$6 \mathrm{p} 87$.

Aron S (2015). Relationship between Nurses' Job Satisfaction and Quality of Healthcare They Deliver. All Theses, Dissertations, and Other Capstone Projects. Paper 506. doi: 10.9790/1959-05114955.

Endang (2008). Analisis Biaya Per Kapita sebagai Upaya Advokasi Pengendalian
Biaya Progam Jaminan Kesehatan', Jembrana, 11(1).

Katrina KS, et al. (2014). An Evaluation of the Factors Influencing the Performance of Registered Nurses at the National Referral Hospital in Namibia, Australian Journal of Business and Management Research New South Wales Research Centre Australia (NSWRCA), 4(2): 47-62.

Mangkunegara AAAP (2013) Manajemen Sumber Daya Manusia Perusahaan, Remaja Rosdakarya. doi: 10.1038/cddis.2011.1.

Mote F (2008) Analisis Indeks Kepuasan Masyarakat (IKM) Terhadap Pelayanan Publik di Puskesmas Ngesrep Semarang, Tesis. Universitas Diponegoro Semarang.

Nurachmah (2011). Persepsi Pemberi Pelayanan Kesehatan Tingkat I terhadap. Program Asuransi Kesehatan/JPKM', Jurnal Manajemen Pelayanan.

Robbins S (2007) Perilaku Organisasi. Jakarta: Indeks.

Suarly, Bachtiar (2009) Manajemen Keperawatan dengan Pendekatan Praktik. Jakarta: Erlangga.

Suyanto (2008) Mengenal Kepemimpinan dan Manajemen Keperawatan di Rumah Sakit. Yogyakarta: Mitra Cendekia.

Wibowo HT (2009). Mengukur Kinerja Pelayanan Kesehatan di Puskesmas Menggunakan Instrumen Kualitas Berorientasi Pelanggan di Kabupaten Aceh Tenggara, Buletin Penelitian Sistem Kesehatan, 12(4). 